\title{
International evidence on the non-linear impact of leverage on corporate cash holdings
}

\author{
Yilmaz Guney \\ University of Surrey, $U K$ \\ Aydin Ozkan* \\ University of York, $U K$ \\ Neslihan Ozkan \\ University of Bristol, UK
}

Journal of Multinational Financial Management, Vol. 17, No. 1, 2007

\begin{abstract}
This paper investigates cash holding behaviour of firms from France, Germany, Japan, the UK and the US using data for 4,069 companies over the period 1996-2000. Our focus is particularly on the relation between cash holdings and leverage. We argue that the impact of leverage on cash balances of firms is likely to be non-monotonic. To the extent that leverage of firms acts as a proxy for their ability to issue debt one would expect a negative (substitution effect) relation between leverage and cash holdings. However, as leverage increases firms are likely to accumulate larger cash reserves to minimise the risk of financial distress and costly bankruptcy. Thus, one would expect a positive (precautionary effect) relationship between cash holdings and leverage at high levels of leverage. Our findings provide strong and robust support for a significant non-linear relation between cash holdings and leverage. Additionally, our results show that the impact of leverage on cash holdings partly depends on country-specific characteristics such as the degree of creditor protection, shareholder protection, and ownership concentration.
\end{abstract}

Current date of revision: February $15^{\text {th }}, 2006$

JEL classification: G3; G32

Keywords: Cash holdings; leverage; investor protection.

* Corresponding author. Department of Economics and Related Studies, University of York, Heslington, York, YO10 5DD, UK. Tel.: + 44 (1904) 434672. Fax: + 44 (1904) 433759. E-mail: ao5@ york.ac.uk. 


\section{Introduction}

The decision of firms to hold substantial cash reserves has recently been a focus of attention in the corporate finance literature (see, e.g., Opler et al., 1999; Dittmar et al., 2003; and Ozkan and Ozkan, 2004). It is argued that the main benefit of holding cash in an imperfect capital market is the increase in firms' ability to take up valuable investment opportunities when they arise and, at the same time, to avoid excessive cost of external financing. However, it is also recognised that there are costs associated with holding cash. For example, managers and controlling shareholders are said to have incentives to retain cash to pursue their own private objectives that may not coincide with those of outside investors (Jensen, 1986).

Prior work on cash holdings identifies several firm-specific factors that are important for firms' cash holding decisions. There has been evidence that firm size, leverage, growth opportunities, and cash flow volatility play a significant role in determining how much cash firms choose to hold. Furthermore, it has been shown that corporate governance is important in explaining the corporate cash holding behaviour. In a recent study, Ozkan and Ozkan (2004) analyse the impact of ownership structure of UK firms on their cash holdings. They provide evidence of a non-monotonic relationship between managerial ownership and cash holdings. They observe that cash holdings first fall and then rise as managerial ownership increases. They also find that firms with ultimate controllers hold higher levels of cash than widely held firms. In a cross-country study, Dittmar et al. (2003) find that firms that operate in countries where shareholder protection is poor tend to hold higher levels of cash. ${ }^{1}$ In contrast, Harford et al. (2004) show that for a sample of US firms, weaker shareholder rights are associated with lower cash holdings.

In this paper, we provide additional international empirical evidence on the determinants of firms' cash holdings. More specifically, we consider both usual firmspecific characteristics and country-specific legal and institutional information for a large sample of firms from Japan, France, Germany, the UK and the US. However, our main contribution lies in the detailed analysis of the impact of leverage on cash holdings. As mentioned above, we are not the first to document the significant relation between the cash holdings and leverage of firms. Prior studies document a positive and

\footnotetext{
${ }^{1}$ Pinkowitz et al. (2003) and Kalcheva and Lins (2003) also find that corporate governance has an impact on firms' cash holdings using a cross country sample. Pinkowitz et al. show that cash holdings are inversely related to the quality of institutions and to the level of financial development of a country, but positively related to the country's level of economic development. Kalcheva and Lins (2003) find that firm-level managerial agency costs interact with external corporate governance in determining the level and value of firms' cash holdings.
} 
monotonic relationship where it is shown that firms tend to increase their cash balances as their indebtedness increases. In this paper, we argue that there are reasons why this relationship may be non-monotonic. To the extent that leverage of firms acts as a proxy for their ability to issue debt one would expect a negative relation between leverage and cash holdings. For example, it is possible that firms can use borrowing as a substitute for holding cash. However, as leverage increases it is more likely that firms will experience financial distress and hence face the threat of bankruptcy. This, in turn, gives firms incentives to accumulate larger cash reserves to minimise the risk of financial distress and costly bankruptcy. Consequently, one would expect a positive relationship between cash holdings and leverage at high levels of leverage. Accordingly, in this paper, we hypothesise a non-linear relationship between leverage and cash holdings.

Furthermore, we argue that the nature of the non-linear relationship between cash holdings and leverage may be affected by country-specific corporate governance characteristics. In an attempt to capture the effect of these characteristics on the relationship between cash balances and leverage we interact leverage with several legal and institutional characteristics, including degree of creditor protection, shareholder protection, and ownership concentration.

Our findings are supportive of a significant non-linear relationship between cash balances of firms and leverage. Consistent with our hypothesis, leverage exerts a negative impact on cash holdings at low levels but the relationship becomes positive at high levels of leverage. We also observe that, in addition to firm-specific variables such as growth opportunities, size, capital expenditures, and dividend payouts, countryspecific ownership and legal characteristics play a significant role in determining cash holdings of firms. We find that stronger anti-director rights have a positive impact on cash holdings whereas ownership concentration has the opposite effect on cash holdings. We also find that the impact of leverage on cash partly depends on the country-specific characteristics.

The remainder of the paper is organised as follows. In section 2, we discuss the relationship between leverage and cash holdings. Section 3 discusses the importance of institutional and legal characteristics in determining firms' cash holdings. In section 4, we review the firm-specific characteristics that are expected to have a significant role in determining firms' cash holding decisions. Section 5 discusses the empirical methods and describes the data. Section 6 presents the results and Section 7 concludes. 


\section{Leverage and cash holdings}

It is recognised that leverage plays a significant role in shaping firms' cash policies. To the extent that the leverage of a firm acts as a proxy for the firm's ability to issue debt one would expect a negative relation between leverage and cash holdings. That is, firms can use borrowing as a substitute for holding cash (John, 1993). Further, firms can maintain financial flexibility through having large cash reserves and/or unused debt capacity (low leverage) suggesting a negative relationship between firms' cash reserves and leverage (see, e.g., Graham and Harvey, 2001).

However, the relationship between cash reserves and leverage can be non-monotonic implying that the marginal effect of increased leverage depends on its current level.

At high levels of leverage firms are more likely to experience financial distress and, thus, accumulate larger cash reserves in order to minimise the risk of costly bankruptcy. It is also argued that financially constrained firms have more incentives to hold large cash balances (see, e.g., Hovakimian and Titman, 2003; and Fazzari, Hubbard and Petersen, 1988). Then, to the extent that firms with high leverage are more likely to be constrained in raising external finance, they would increase their cash balances as a precautionary motive. These arguments suggest that the relationship between cash holdings and leverage can become positive at high levels of leverage.

To test the hypothesized non-monotonic nature of the relationship between cash holdings and leverage we estimate a quadratic model that implies one turning point. That is, as leverage increases, we expect to observe first a negative (substitution effect) then a positive (precautionary effect) effect exerted by leverage on cash holdings.

\section{Country-specific characteristics and cash holdings}

This section contains a discussion of the role of country-specific factors, such as shareholder protection, creditor protection, and ownership structure in affecting cash holding incentives of firms.

\subsection{Legal environment and cash holdings}

Conflicts of interests between corporate insiders, namely managers and controlling shareholders, and outside investors can create agency costs, which would in turn increase the cost of external financing. One such example is the agency problem of free cash flow in excess of the amount required to fund all valuable investment projects (Jensen, 1986). That is, managers have incentives to increase the amount of funds under their control because this to some extent enables them to spend it as they wish, i.e. 
squandering funds by consuming perquisites and/or making inefficient investment decisions.

What role does the legal environment play in reducing the costs of this type of agency problem? It is argued that the severity of agency costs vary with the degree of protection the outside investors receive, which has implications for the ability of firms to raise external debt and equity finance (La Porta et al. 1997, 1998). For example, in a country where the protection of outside investors is poor, expected agency costs will be higher and firms' access to external finance funds will be limited. In such an environment, firms are more likely to accumulate cash. In this paper, we distinguish between shareholder and creditor protection. As also discussed in previous studies, it is more likely that firms will hold less cash in countries with strong shareholder protection $^{2}$. This is due to lower expected costs associated with the agency problem described above and hence the lower cost of external equity.

However, we argue that the impact of creditor protection on cash holdings can be different from that of shareholder protection. Strong creditor protection can increase the likelihood of bankruptcy when firms experience financial distress. We predict that this makes managers more conservative in relation to the levels of cash they hold. As a result, they accumulate more cash in an attempt to reduce the threat by strong creditors of bankruptcy in financial distress.

In this paper, we investigate the impact of legal characteristics on incentives of firms to hold cash by considering two indicators developed by La Porta et al. (1997). First, as a proxy for shareholder rights, we employ their measure of Anti-director rights index. This index aggregates such elements of shareholder rights as the ability to vote by mail, the possibility of cumulative voting for directors, the ease of calling an extra ordinary shareholder meeting, and the availability of legal mechanisms of protecting minority shareholders from expropriation by directors. Second, as a proxy for creditor rights, creditor rights index is used. This aggregates the various rights that secured creditors might have in liquidation and reorganisation. Restrictions on the managers' ability to seek unilateral protection from creditors, mandatory dismissal of management in reorganisation, lack of automatic stay on assets, and absolute priority for secured creditors all contribute to the calculation of this index For details about the anti-director rights index and creditor rights index ${ }^{3}$.

\footnotetext{
${ }^{2}$ See, for example, Dittmar et al. (2003) and Pinkowitz et al. (2003).

${ }^{3}$ See La Porta et al. (1997).
} 
Table 1 presents the values of these indicators for France, Germany, Japan, the UK and the US. It is clear that there is significant variation in these measures across the countries in our sample. Creditor rights are strongest in the UK. The weakest scores belong to France and the US, 0 and 1, respectively. Out of 4 the scores of Japan and Germany are 2 and 3, respectively. As for the anti-director rights, the US has the highest score with 5 and Germany has the weakest one with a score of 1 . The UK has also a high score of 4 out of 5. France and Japan score 2 and 3 out of 5, respectively. We also calculate an alternative proxy for investor protection using the creditor and anti-director rights scores in the table. This is called creditor ratio and it is defined by the ratio of creditor rights to anti-director rights. We argue that it measures the relative importance of creditor rights to shareholder rights. We incorporate this variable in our analysis mainly because it is possible that creditor and anti-director rights measures are not independent of each other and hence it may be difficult to disentangle the effect of each measure on cash holdings.

\subsection{Ownership, control and cash holdings}

A major institutional difference among the countries in our sample is due to ownership concentration. As can be observed from Table 1, the ownership of firms in the US, the UK and Japan is largely dispersed, while it is highly concentrated in France and Germany. Not surprisingly, the lowest ownership concentration is observed in the US and the UK with 12 percent and 13 percent, respectively. The concentration is 15 percent for Japan while it is 24 percent and 50 percent for France and Germany, respectively. ${ }^{4}$

Ownership concentration might have important implications for potential agency problems. It is argued that one way to control the agency problem between managers and shareholders is to effectively monitor managers. However, an average shareholder might not have strong incentives to monitor managers, as the costs of monitoring are likely to outweigh the benefits (Grossman and Hart, 1988). In contrast, large shareholders, having claims on a large fraction of the firm's cash flows, can monitor managers more effectively. Consequently, in the presence of a large shareholder,

\footnotetext{
${ }^{4}$ There is also evidence that there are substantial differences in the nature of ownership across the countries in our sample (see, for example, Claessens et al, 2000 for Japan and Faccio and Lang, 2002 for others). In the UK nearly 64 percent of non-financial firms and in Japan 79.8 percent of all firms are
} 
managerial discretion is likely to be curbed and agency costs between management and shareholders are expected to be lower (Stiglitz, 1985; Shleifer and Vishny, 1986). This, in turn, suggests that the cost of external financing would be lower for firms with large shareholders, implying less need to hold large cash balances. ${ }^{5}$

\section{Firm-specific characteristics that influence cash holding decision}

In this section, we provide a brief review of the firm-specific characteristics identified by theory as relevant in determining firms' cash holding policies.

\subsection{Growth opportunities}

It is predicted that there is a positive relation between cash reserves and growth opportunities of firms, based on the view that external financing is more costly for firms with greater growth opportunities. There are at least two explanations as to why there is a wedge between the costs of internal and external finance. First, growth firms face higher agency costs because, when the investment opportunity set of firms consists of growth opportunities, firms with risky debt are more likely to pass up some of the valuable investment opportunities (Myers, 1977). Second, it is argued that asymmetric information is more severe between insiders and outside investors for firms whose values are largely determined by growth options (Myers and Majluf, 1984). Consequently, firms with greater growth opportunities accumulate more cash to avoid the necessity to resort to costly external financing and hence the possibility that they give up valuable investment opportunities.

It can also be argued that firms with greater growth opportunities are expected to incur higher bankruptcy costs (see, for example, Williamson, 1988; and Harris and Raviv, 1990; Shleifer and Vishny, 1992). Growth opportunities are intangible in nature and their value will fall significantly in financial distress and bankruptcy. Larger expected costs would in turn imply that firms with greater growth opportunities have larger cash holdings to avoid financial distress and bankruptcy.

widely held at the 20 percent threshold. However, in France and Germany percentage of firms that are widely held is relatively much lower, respectively 12 and 10 percent.

${ }^{5}$ One could, however, argue that large shareholders might have incentives to increase the amount of funds under their control to consume corporate benefits at the expense of minority shareholders. One way of doing it is obviously to accumulate large amounts of cash. With higher levels of cash holdings it is less likely that controlling shareholders will relinquish control and share the efficiency gains with outside shareholders. These arguments suggest a positive relationship between ownership concentration and cash balances. 
As a proxy for growth opportunities of firms we use the market-to-book ratio $(M K T B O O K)$ defined as the ratio of book value of total assets minus the book value of equity plus the market value of equity to book value of assets.

\subsection{Cash flow and cash flow variability}

Kim et al. (1998) argue that cash flow provides a ready source of liquidity for investment and maturing liabilities. Also, the risk of having to pass up investment opportunities and facing financial distress is lower for firms with higher cash flows. Accordingly, such firms can afford to have lower cash holdings. We measure cash flows $(C F L O W)$ as the ratio of pretax profit plus depreciation to total assets. ${ }^{6}$

Firms with more volatile cash flows are expected to hold more cash in an attempt to mitigate the expected costs of liquidity constraints. As mentioned earlier, it may be costly to be short of cash and marketable securities if the firm has to pass up valuable investment opportunities. There is evidence that firms with cash shortfalls do indeed fail to take up some of the valuable growth opportunities. For example, Minton and Schrand (1999) show that firms with higher cash flow volatility permanently forgo investment rather than reacting to cash flow shortfalls by changing the discretionary investment timing. The measure we use for cash flow variability (VARIABILITY) is the standard deviation of cash flows divided by average total assets over the five year period from 1996 to $2000 .^{7}$

\subsection{Size}

It is argued that larger firms are more likely to be diversified and thus less likely to experience financial distress (see, e.g., Titman and Wessels, 1988); and smaller firms face more borrowing constraints and higher costs of external financing than larger firms (Whited, 1992; and Fazzari and Petersen, 1993). The above argument suggests a negative relationship between size and cash holdings of firms. Also, to the extent that size is an inverse proxy for the degree of informational asymmetry between insiders and outside investors, a negative relation should be expected between size and cash

\footnotetext{
${ }^{6}$ However, it is argued that in the presence of asymmetric information and signalling problems associated with external funding, firms have a preference for internal over external finance (Myers and Majluf, 1984). This implies a positive influence of cash flow. Also, to the extent that cash flows are a proxy for growth options the relationship between cash flow and cash holdings should be positive.

7 Although there are alternative definitions of cash flow variability used in different strands of the literature we use the one that has been adopted in the cash literature (see, e.g., Kim et al., 1998; Minton and Schrand, 1999; and Ozkan and Ozkan, 2004). However, our results remain unchanged with alternative definitions, e.g., the standard deviation of the first difference in cash flows scaled by average book value of the assets.
} 
holdings. We use the natural logarithm of total sales in 1996 prices as a proxy for the size of firms (SIZE)

\subsection{Liquidity}

We predict that there is a negative relation between the firm's cash holdings and its liquid assets. To the extent that firms can use other liquid assets besides cash when they have cash shortfalls, these assets can be seen as substitutes for cash holdings. We use the ratio of net working capital, minus cash to total assets $(L I Q)$ as a proxy for liquid asset substitutes.

\subsection{Other control variables}

Similar to other studies, we also control for dividend policy and capital expenditures of firms (see, for example, Opler et al., 1999 and Dittmar et al., 2003). For dividend policy we use a dividend dummy, DIVIDEND, which is equal to 1 if a firm pays dividend for a given year. To control for the possibility that the firm's cash holding policy is simply a function of its capital expenditures, we include the ratio of capital expenditures to total assets, CAPEX. Finally, industry dummies are included in all specifications.

\section{Empirical Methodology and Data}

\subsection{Cross-sectional estimation}

We estimate a cross-sectional cash model using the average values of each of the independent variables (except variability and country-specific characteristics) over four years in an attempt to mitigate problems that might arise due to short-term fluctuations or extreme values in one year. We measure cash holdings (the dependent variable) in 2000 and the explanatory variables over the period 1996-1999. This is done to control for the problem of endogeneity. Using past values reduces the likelihood of observed relations reflecting the effects of cash holdings on firm-specific factors.

\subsection{Data}

For our empirical investigation we use a sample of listed firms from France, Germany, Japan, the UK and the US over the period 1996-2000. There are mainly two reasons why we limit our analysis to these countries. First, there is evidence that these countries differ widely in terms of institutional and legal characteristics. Analysing cash 
holdings for these countries may shed more light on the importance of these factors. Second, we were able to construct data for relatively longer periods and a large number of firms for each country.

Our initial sample is the set of all firms for which data are available on the Datastream database, which provides both accounting data for firms, and market value of equity. Firms, which operate in the financial sector, were excluded. Missing firmyear observations for any variable in the model during the sample period were dropped. Finally, from these firms, only those with at least five continuous time series observations during the sample period were chosen. These criteria have provided us with a total number of 4,069 firms, which represents 20,353 firm-year observations.

\section{[INSERT TABLE 2 HERE]}

Table 2 reports the descriptive statistics for the main variables used in our analysis. The average cash-to-asset ratio, our dependent variable in the regression analysis, which is defined as the ratio of total cash and equivalent items to total assets, is highest for Japanese firms, 17 percent, and lowest for the US firms at 7 percent. Higher corporate cash holdings in Japan is explained by the incentives of banks to act at the expense of non-bank firms by encouraging them to hold relatively high levels of cash (Pinkowitz and Williamson, 2001). The lowest observed mean value for the US firms ( 7 percent) may be an indication of the reduced incentives of firms to accumulate cash when they have relatively easy access to external capital markets. For UK and France, average cash-to-asset ratio is 11 percent and 12 percent, respectively. Finally, the German companies hold on average about 8.7 percent of their total assets in cash and marketable securities.

\section{[INSERT TABLE 3 HERE]}

Table 3 reports univariate comparisons of the firm-specific characteristics by cashto-assets quartile ${ }^{8}$. We carry out this analysis by constructing quartiles of cash holdings ratio and investigate whether the firm-specific characteristics of high-cash companies (those firms in the fourth quartile) differ significantly from those of low-cash companies (those firms in the first quartile). There is strong evidence that high-cash firms display significantly different characteristics from low-cash firms and differences are significant

\footnotetext{
${ }^{8}$ A similar comparison is also made in Opler et al. (1999).
} 
at the 1 percent level except for the market-to-book ratio for which the significance level is 5 percent. Our results reveal that firms with larger cash balances seem to have greater growth opportunities, though the relationship is not monotonic. In contrast to the expected negative relation between cash holdings and firm size, the univariate relation shows that firms with the most cash have larger size than those with the least cash. Cash flow variability decreases monotonically with the cash ratio, which is not in line with the predicted positive relation between cash holdings and cash flow variability. As expected, the relation between cash flow and cash holdings is negative. Cash flows decrease monotonically with cash holdings, which is consistent with the view that cash flow provides a ready source of liquidity for investment expenditures. Furthermore, capital expenditures decrease monotonically across quartiles of cash holdings.

Finally, as for leverage, the difference between the leverage ratio of firms in the first quartile and that of firms in the fourth quartile is significant. High-cash firms have much lower average leverage ratio than low-cash firms. However, despite the dramatic fall in the fourth quartile, the average leverage ratio seems stable over the first three quartiles.

Table 3 (Panel B) also presents a basic test of the difference in means for the dependent variable, the cash-to-assets ratio. We carry out this test across countries using the average cash values over the sample period for each country. That is, the average value of cash holdings for firms in each country is compared with that in all other countries in our sample. This analysis provides strong evidence that the average value of cash holdings of firms differ significantly across countries.

\section{Results}

\subsection{Country specific effects}

Table 4 presents the first set of cross-sectional results. In the first column, we present OLS results for the pooled regression analysis where, in addition to firm-specific characteristics and industry dummies, country dummies are incorporated to test the null hypothesis that cash holdings of firms do not significantly change across countries. The $\mathrm{UK}$ is taken as the base country in the analysis.

The preliminary findings reveal that except for Germany there is a significant country specific component to firms' cash holdings. The estimated coefficients of the dummy variables for Japan and France are positive and significant at 1 percent level, suggesting that Japanese and French firms hold more cash than British and German firms. This is consistent with the average values of cash holdings across countries in 
Table 1. For example, the regression analysis suggests that the average difference in cash holdings of firms between France and the UK is about 4 percent controlling the firm-specific characteristics. Overall, our results suggest that country-specific factors play a significant role in determining firms' cash holding decisions.

The pooled regression results also indicate that firms' cash holdings increase with volatility of cash flows, market-to-book ratio and liquidity position of firms, and decrease with dividend payouts of firms. Furthermore, as expected, the results suggest that firms with greater capital expenditures tend to have lower amounts of cash. There is, however, no evidence to support the view that an increase in firm size decreases firms' incentives to accumulate more cash.

\section{[INSERT TABLE 4 HERE]}

Last but not least, the results show that the leverage decision of firms impacts their cash balances significantly and in a non-linear fashion. More specifically, we first observe a negative relationship between leverage and cash holdings. However, the relationship between the two variables turns out to be positive at higher levels of leverage. These findings support the view that borrowing can initially be seen as a substitute for holding cash. However, it seems that the probability of financial distress, which is a function of leverage, leads firms to accumulate larger cash reserves at greater levels of leverage in an attempt to minimise the risk of costly bankruptcy. These results provide the preliminary evidence of the hypothesised non-linear leverage effect on cash holdings.

In columns 2 to 6 , we provide the cash regression results with respect to each country separately. The results with regard to the majority of variables are similar to those in the pooled regression analysis. More specifically, the relationship between cash holdings and leverage is first negative and significant at the 1 percent level for all countries. Furthermore, the estimated coefficient of the quadratic leverage term is positive and significant at the 1 percent level across all countries. These findings provide further support for the non-linear relation between cash holdings and leverage. We also estimated the turning points - points at which the sign of the relationship between cash holdings and leverage changes from negative to positive - for each country. We find a range of values of leverage from about 39 percent (for UK) to about 59 percent (for Japan). The values for France, the US and Germany are about 48 percent, 49 percent and 54 percent, respectively. 
As for the impact of other financial variables, liquidity has a negative and significant impact on firms' cash holdings for all except the US firms. The estimated relation between cash holdings and leverage for the US firms is positive and significant. Consistent with the prediction, the effect of growth opportunities on cash holdings is positive and significant except in Germany. In line with the hypothesis of financing hierarchy model specifying internal finance as the least costly financing form, cash holdings are negatively related to capital expenditures. However, this relation is positive but insignificant for the US. As for firm size, the estimated coefficient of size is positive and significant only for the Japanese companies, suggesting that larger firms in Japan tend to hold larger amounts of cash. However, more in line with the theoretical predictions, we find for France, Germany and the UK a negative impact exerted by firms' size on their cash holdings. Similarly, we have mixed findings regarding the dividend variable. The estimated coefficient is negative and significant for the firms in the US and the impact of dividend on cash holdings is positive and significant in Germany. Dividend payouts of firms do not seem to have any significant impact on their cash holdings in France, Japan and the UK.

Finally, we do not find a statistically significant relation between cash holdings and cash flow variability in all countries except the US where the relation between cash holdings and the variability of cash flows is positive and significant at the 1 percent level. This partial evidence for the US supports the view that firms with more volatile cash flows are expected to hold more cash in an attempt to mitigate the expected costs of liquidity constraints.

\subsection{Country specific effects and the impact of leverage}

In Table 5, we continue to carry out our cross-sectional investigation. In order to incorporate legal and institutional characteristics into the analysis, we focus on pooledregression analysis. In the first three columns, in addition to firm-specific factors and industry dummies, we incorporate the proxies for investor protection, namely creditor righs (Creditor) and shareholders' rights (Anti-director), and the ownership concentration variable, Ownership. We also investigate whether the nature of the relationship between cash holdings and leverage changes with legal protection of investors and ownership concentration. To this end, in each model we interact the leverage terms with the proxies for investor protection and ownership concentration. Moreover, in Table 5, Panel B, we report the turning points computed for each specification using the values of country-specific characteristics. 
Overall, the results suggest that legal and institutional characteristics play an important role in determining cash holdings of firms. However, we provide somewhat mixed results regarding some of the characteristics. More specifically, there is no support for the view that firms in countries with better creditor protection are expected to hold larger cash balances. This result does not provide support for the argument that the likelihood of bankruptcy for financially distressed firms is higher in countries with higher creditor protection and firms in such countries hold higher cash reserves that may help firms in financial distress avoid bankruptcy. However, the estimated coefficients of interactions suggest that creditor protection may have some impact on the nature of the relationship between cash holdings and leverage. In particular, we find that the substitution effect of leverage on cash holdings gets smaller as the creditor protection increases. This is given by the positive estimated coefficient of the first interaction term, i.e. (Leverage*Creditor). Additionally, column (2) of Table 5 (Panel B) demonstrates the turning points computed for each value of creditor protection. As shown in this table, the substitution effect of leverage on cash holdings reduces as the creditor protection increases. We observe that the leverage ratio at which the nature of the relation between cash holdings and leverage changes (i.e. it turns from negative to positive) decreases as the creditor protection rises. For example, the computed turning point drops to 46 percent from 55 percent as the creditor protection increases from 0 to the highest value of 4 .

\section{[INSERT TABLE 5 HERE]}

The results in the second column of Table 5 (Panel A) reveal that anti-directors rights exert a positive influence on firms' cash holdings. That is, firms in countries with stronger anti-director rights hold larger cash balances. This finding is not in line with the view that expected agency costs are lower in countries with better investment protection and hence firms in these countries do not need to accumulate large cash balances to finance their future investment opportunities. This is expected to happen simply because the cost of external finance would be lower as agency costs decline. However, our findings with regard to the interaction variables provide interesting insights into the relation between cash and leverage and the conditional impact of leverage on cash holdings. Our results reveal that as anti-director rights index increases the negative impact of debt on cash holdings become more apparent, suggesting a stronger substitution effect of borrowing for cash holdings. Similarly, we find that the 
positive impact of leverage on cash becomes stronger as the shareholders' rights increases. Additionally, Table 5 (Panel B) reveals that the computed turning points decrease as the value of anti-directors index increases. Whereas the turning point for the lowest anti-directors value is 57 percent it decreases to 50 percent for the highest value of anti-directors rights.

It is possible that creditor and anti-director rights are correlated ${ }^{9}$. Thus, we have so far avoided including them in the same specification. However, we incorporate in our analysis an alternative proxy for the protection of firms' creditors, Creditor Ratio, defined as the ratio of creditor rights to anti-director rights, which measures the relative importance of creditor rights with respect to the shareholders' rights. Our results show that this ratio has a negative impact on firms' cash holdings and the interaction terms reveal that the substitution (negative) effect of leverage on cash holdings reduces as the creditor ratio increases. That is, firms in countries with relatively better creditor protection are less likely to hold large cash balances. Furthermore, the positive impact of leverage observed at higher levels of leverage seems to be also decreasing as the value of this ratio increases. Finally, we observe that in Table 5 (Panel B) the turning points computed for each value of creditor ratio changes between 0.52 and 0.48 .

Next, in the column 4 of Table 5 (Panel A) we replace creditor ratio with ownership concentration, measured as the median ownership by the three largest shareholders for the 10 largest firms. We do so because ownership concentration may act as a substitute to other legal characteristics ${ }^{10}$. The results reveal that higher ownership concentration leads to lower cash holdings. To the extent that large shareholders have more incentives and better ability to monitor and discipline the firm's management this result may indicate that the expected managerial agency costs are lower for firms with greater ownership concentration, which in turn reduces the need for firms to accumulate large amount of cash. Furthermore, we observe that the negative substitution effect of leverage reduces as the ownership concentration increases. This is given by the positive estimated coefficient of the first interaction term, i.e. (Leverage*Ownership). However, the estimated coefficient of the second interaction term is insignificant.

The above results suggest that leverage has a strong and robust non-linear effect on firms' cash holdings. Moreover, the nature of the relation between cash reserves and

\footnotetext{
${ }^{9}$ La Porta et al.(1997) argue that legal origin can influence both shareholder and creditor rights; e.g., common law countries give both shareholders and creditors relatively stronger protection, while civil law countries give them weaker protection.

${ }^{10}$ Shleifer and Vishny (1997) argue that higher ownership concentration may be a reflection of poor investor protection.
} 
leverage seems to change from one country to another depending upon country-specific characteristics. Both the substitution and precautionary effects tend to weaken in the presence of strong creditor rights and ownership concentration. However, better shareholder rights do not lead to the same conclusion. More specifically, both the negative impact (substitution) and the positive effect (precautionary) of leverage on cash holdings become stronger with greater anti-director rights.

\section{Summary and Conclusions}

In this paper we have investigated firms' cash holding decisions by using firm-level data from Japan, France, Germany, UK and US. There are mainly two important features of our analysis, which, we believe, extend our understanding of the cash holding behaviour of firms. First, this paper provides a detailed analysis of the relationship between cash holdings and leverage. More specifically, we establish that borrowing decisions of firms exert a non-linear impact on their cash holding decisions. We argue that this stems from the fact that leverage acts as a substitute for cash holdings but at the same time increases the probability of financial distress. One hence observes first a negative relationship at lower levels of leverage and the observed relation becomes positive at high leverage levels.

Secondly, we focus on the importance of corporate governance issues. In doing so, we incorporate legal and institutional characteristics such as ownership concentration, degree of creditor and shareholder protection into our analysis. We argue that strong creditor protection increase the probability of bankruptcy in financial distress, which would in turn imply more accumulation of cash as a precaution to avoid financial distress. Last but not least, we interact leverage with these legal and institutional characteristics to test if the nature of the relationship between cash and leverage changes across countries depending on those country-specific characteristics.

We find that institutional and legal characteristics as well as firm-specific characteristics play a significant role in determining cash holdings of firms. Our results provide evidence that the degree of investor protection can influence cash policies of firms. More specifically, we find that strong investor protection and high ownership concentration seem to lead firms to hold lower cash balances. Furthermore, the impact of leverage on cash changes with legal and institutional characteristics. 


\section{References}

Claessens, S., Djankov, S., Lang L.H.P, 2000. The separation of ownership and control in East Asian corporations. Journal of Financial Economics 58, 81-112.

Dittmar, A., Mahrt-Smith, J., and Servaes, H., 2002. International corporate governance and corporate cash holdings. Journal of Financial and Quantitative Analysis 38,111133.

Faccio, M., Lang, L.H.P., 2002. The ultimate ownership of Western European corporations. Journal of Financial Economics 65, 365-395.

Fazzari, S.M., Petersen, B., 1993. Working capital and fixed investment: New evidence on financing constraints. Rand Journal of Economics 24, 328-342.

Fazzari, S.M., Hubbard, R.G., and Petersen, B., 1988. Financing constraints and corporate investment. Brokking Papers on Economic Activity, 141-195.

Graham, J.R. and Harvey, C.R , 2001. The theory and practice of corporate finance: evidence from the field. Journal of Financial Economics 60, 187-243.

Grossman, S.J., Hart, O., 1988. One share-one vote and the market for corporate control. Journal of Financial Economics 20, 175-202.

Harford, J., Sattar, A.M., Maxwell, W.F. 2004. Corporate governance and cash holdings. Working paper, University of Washington.

Harris, M. and Raviv, A., 1990. Capital structure and the informational role of debt. Journal of Finance 45, 321-49.

Hovakimian, G.,Titman, S.,2003. Corporate investment with financial constraints: Sensitivity of investment to funds from voluntary asset sales. NBER working paper no:9432.

Jensen, M.C., 1986. Agency costs of free cash flow, corporate finance and takeovers. American Economic Review 76, 323-39.

John, T.A., 1993. Accounting measures of corporate liquidity, leverage, and costs of financial distress. Financial Management 22, 91-100.

Kalcheva, I., Lins, K.V. 2003. International evidence on cash holdings and expected managerial agency problem. Working paper, University of Utah.

Kim, Chang-Soo, Mauer, D.C., Sherman, A.E., 1998. The determinants of corporate liquidity: theory and evidence. Journal of Financial and Quantitative Analysis 33, 305334.

La Porta, R., Lopez-de-Silanes, F., Shleifer, A., Vishny, R., 1997. Legal determinants of external finance. Journal of Finance 52, 1131-1150.

La Porta, R., Lopez-de-Silanes, F., Shleifer, A., Vishny, R., 1998. Law and finance. Journal of Political Economy 106, 1113-1155. 
Minton, B.A.and Schrand C., 1999. The impact of cash flow volatility on discretionary investment and the costs of debt and equity financing. Journal of Financial Economics 54, 423-460.

Myers, S.C, 1977. Determinants of corporate borrowing. Journal of Financial Economics 5, 147-175.

Myers, S.C., Majluf, N.S.. 1984. Corporate financing and investment decisions when firms have information that investors do not have. Journal of Financial Economics 13, 187-221.

Opler, T., Pinkowitz, L., Stulz, R., and Williamson, R., 1999. The determinants and implications of cash holdings. Journal of Financial Economics 52, 3-46.

Ozkan, A., Ozkan, N., 2004. Corporate cash holdings: an empirical investigation of UK companies. Journal of Banking and Finance 28, 2103-2134.

Pinkowitz, L., Stulz, R., Williamson, R., 2003. Why do firms in countries with poor protection of investor rights hold more cash? Working paper, Georgetown University.

Pinkowitz, L., Williamson, R., 2001. Bank power and cash holdings: Evidence from Japan. Review of Financial Studies 14, 1059-1082.

Shleifer, A., Vishny, R.W., 1986. Large shareholders and corporate control. Journal of Political Economy 95, 461-488.

Shleifer, A. and Vishny, R.W., 1992. Liquidation values and debt capacity: A market equilibrium approach. Journal of Finance 47, 1343-1366.

Stiglitz, J., 1985. Credit markets and the control of capital. Journal of Money, Credit and Banking 17, 133-152.

Titman, S., Wessels. R., 1988. The determinants of capital structure choice. Journal of Finance 43, 1-19.

Whited, T., 1992. Debt, liquidity constraints, and corporate investment: Evidence from panel data. Journal of Finance 47, 1425-60.

Williamson, O., 1988. Corporate finance and corporate governance. Journal of Finance $43,567-91$. 
Table 1

Institutional and legal characteristics

\begin{tabular}{lcccc}
\hline & $\begin{array}{c}\text { Ownership } \\
\text { Concentration }\end{array}$ & Creditor rights & $\begin{array}{c}\text { Anti-director } \\
\text { rights }\end{array}$ & Creditor ratio \\
\hline France & 0.24 & 0 & 2 & 0 \\
Germany & 0.50 & 3 & 1 & 3 \\
Japan & 0.13 & 2 & 3 & 0.67 \\
UK & 0.15 & 4 & 4 & 1 \\
US & 0.12 & 1 & 5 & 0.20 \\
\hline
\end{tabular}

For each country ownership concentration denotes the median ownership by the three largest shareholders for the 10 largest non-financial firms. Creditor rights denotes an index aggregating creditor rights; the index ranges from 0 to 4 . Anti-director rights is an index aggregating shareholder rights and ranging from 0 to 5. Creditor ratio is the ratio of creditor rights to anti-director rights. Source: La Porta et al. $(1997,1998)$. 
Table 2

Descriptive statistics for the main variables

\begin{tabular}{|c|c|c|c|c|c|c|c|}
\hline & Mean & Std. Dev & Min & $25 \%$ & Median & $75 \%$ & $\operatorname{Max}$ \\
\hline \multicolumn{8}{|l|}{ France } \\
\hline Cash & 0.12 & 0.11 & 0.00 & 0.05 & 0.08 & 0.17 & 0.59 \\
\hline Cash Flow & 0.08 & 0.08 & -0.86 & 0.05 & 0.08 & 0.11 & 0.39 \\
\hline Leverage & 0.22 & 0.13 & 0.00 & 0.12 & 0.21 & 0.31 & 0.90 \\
\hline Liquidity & 0.01 & 0.14 & -0.31 & -0.09 & 0.01 & 0.11 & 0.49 \\
\hline Mkt-to-Book & 1.65 & 1.04 & 0.66 & 1.06 & 1.32 & 1.93 & 9.51 \\
\hline Size & 15.01 & 1.81 & 10.38 & 13.73 & 14.81 & 16.30 & 19.08 \\
\hline Capex & 0.04 & 0.07 & 0.00 & 0.01 & 0.02 & 0.05 & 0.51 \\
\hline Variability & 0.07 & 0.06 & 0.01 & 0.03 & 0.05 & 0.08 & 0.62 \\
\hline \multicolumn{8}{|l|}{ Germany } \\
\hline Cash & 0.09 & 0.12 & 0.00 & 0.01 & 0.04 & 0.11 & 0.82 \\
\hline Cash Flow & 0.07 & 0.08 & -0.60 & 0.05 & 0.08 & 0.11 & 0.25 \\
\hline Leverage & 0.21 & 0.19 & 0.00 & 0.04 & 0.18 & 0.34 & 0.79 \\
\hline Liquidity & 0.11 & 0.25 & -1.39 & -0.03 & 0.11 & 0.25 & 0.99 \\
\hline Mkt-to-Book & 1.52 & 0.96 & 0.41 & 1.07 & 1.26 & 1.64 & 12.68 \\
\hline Size & 12.39 & 2.86 & 0.00 & 11.27 & 12.69 & 13.94 & 18.47 \\
\hline Capex & 0.08 & 0.05 & 0.00 & 0.04 & 0.07 & 0.10 & 0.27 \\
\hline Variability & 0.07 & 0.05 & 0.00 & 0.04 & 0.05 & 0.08 & 0.42 \\
\hline \multicolumn{8}{|l|}{ Japan } \\
\hline Cash & 0.17 & 0.11 & 0.00 & 0.09 & 0.14 & 0.22 & 0.76 \\
\hline Cash Flow & 0.03 & 0.04 & -0.19 & 0.01 & 0.03 & 0.05 & 0.18 \\
\hline Leverage & 0.304 & 0.20 & 0.00 & 0.14 & 0.29 & 0.44 & 0.91 \\
\hline Liquidity & -0.04 & 0.15 & -1.06 & -0.13 & -0.03 & 0.06 & 0.48 \\
\hline Mkt-to-Book & 1.15 & 0.55 & 0.510 & 0.92 & 1.04 & 1.19 & 10.53 \\
\hline Size & 18.46 & 1.44 & 14.39 & 17.52 & 18.28 & 19.28 & 23.55 \\
\hline Capex & 0.06 & 0.05 & 0.00 & 0.03 & 0.05 & 0.08 & 0.57 \\
\hline Variability & 0.03 & 0.02 & 0.00 & 0.02 & 0.03 & 0.04 & 0.42 \\
\hline \multicolumn{8}{|l|}{ UK } \\
\hline Cash & 0.11 & 0.15 & 0.00 & 0.02 & 0.06 & 0.14 & 1.00 \\
\hline Cash Flow & 0.08 & 0.11 & -0.76 & 0.06 & 0.10 & 0.13 & 0.34 \\
\hline Leverage & 0.17 & 0.13 & 0.00 & 0.07 & 0.17 & 0.25 & 0.80 \\
\hline Liquidity & 0.03 & 0.18 & -0.74 & -0.08 & 0.01 & 0.14 & 0.81 \\
\hline Mkt-to-Book & 1.90 & 1.38 & 0.24 & 1.07 & 1.44 & 2.18 & 10.09 \\
\hline Size & 9.27 & 2.06 & 3.18 & 7.91 & 9.14 & 10.62 & 15.63 \\
\hline Capex & 0.06 & 0.05 & 0.00 & 0.03 & 0.05 & 0.08 & 0.43 \\
\hline Variability & 0.09 & 0.06 & 0.01 & 0.05 & 0.08 & 0.11 & 0.40 \\
\hline \multicolumn{8}{|l|}{ US } \\
\hline Cash & 0.07 & 0.11 & 0.00 & 0.01 & 0.03 & 0.07 & 0.85 \\
\hline Cash Flow & 0.16 & 0.08 & -0.14 & 0.12 & 0.15 & 0.20 & 0.89 \\
\hline Leverage & 0.28 & 0.17 & 0.00 & 0.16 & 0.27 & 0.38 & 0.99 \\
\hline Liquidity & 1.92 & 1.26 & 0.14 & 1.14 & 1.66 & 2.30 & 16.60 \\
\hline Mkt-to-Book & 1.95 & 1.72 & 0.39 & 1.21 & 1.54 & 2.16 & 40.02 \\
\hline Size & 13.51 & 1.53 & 6.17 & 12.46 & 13.44 & 14.48 & 18.54 \\
\hline Capex & 0.07 & 0.06 & 0.00 & 0.04 & 0.06 & 0.09 & 0.73 \\
\hline Variability & 0.08 & 0.06 & 0.01 & 0.04 & 0.07 & 0.11 & 0.38 \\
\hline
\end{tabular}

Cash is the ratio of total cash and equivalent items to total assets. Cash Flow is the ratio of pre-tax profit plus depreciation to total assets. Leverage is the ratio of total debt to total assets. Liquidity is the ratio of current assets minus total cash and equivalent to total assets. Mkt-to-Book is the ratio of book value of total assets minus the book value of equity plus the market value of equity to book value of assets. Size is the log of total sales in 1996 prices. Capex is the ratio of capital expenditures to total assets. Variability is the ratio of the standard deviation of cash flows to average total assets. 
Table 3

Panel A: Univariate analysis of the variables (all countries pooled)

\begin{tabular}{lccccc}
\hline & $\begin{array}{c}\text { First } \\
\text { Quartile }\end{array}$ & $\begin{array}{c}\text { Second } \\
\text { Quartile }\end{array}$ & $\begin{array}{c}\text { Third } \\
\text { Quartile }\end{array}$ & $\begin{array}{c}\text { Fourth } \\
\text { Quartile }\end{array}$ & $\begin{array}{c}\text { T-statistic } \\
\text { (p-value) }\end{array}$ \\
\hline Cash range & 0.00 to & 0.02 to & 0.08 to & 0.17 to & \\
& 0.02 & 0.08 & 0.17 & 1.00 & \\
Cash & & & & & \\
& 0.01 & 0.05 & 0.12 & 0.29 & -69.46 \\
Cash Flow & $(0.01)$ & $(0.05)$ & $(0.12)$ & $(0.25)$ & $(0.00)$ \\
& 0.12 & 0.09 & 0.06 & 0.06 & 14.63 \\
Leverage & $(0.12)$ & $(0.09)$ & $(0.05)$ & $(0.05)$ & $(0.00)$ \\
& 0.28 & 0.28 & 0.28 & 0.18 & 12.97 \\
Liquidity & $(0.27)$ & $(0.26)$ & $(0.27)$ & $(0.14)$ & $(0.00)$ \\
& 0.90 & 0.55 & 0.23 & 0.40 & 9.61 \\
Mkt-to-Book & $(0.65)$ & $(0.09)$ & $(-0.00)$ & $(0.04)$ & $(0.00)$ \\
& 1.58 & 1.62 & 1.46 & 1.73 & -2.86 \\
Size & $(1.34)$ & $(1.26)$ & $(1.12)$ & $(1.19)$ & $(0.00)$ \\
& 12.28 & 13.94 & 15.68 & 15.32 & -19.08 \\
Capex & $(12.67)$ & $(13.70)$ & $(17.16)$ & $(17.09)$ & $(0.00)$ \\
& 0.07 & 0.07 & 0.06 & 0.06 & 5.65 \\
Variability & $(0.06)$ & $(0.06)$ & $(0.05)$ & $(0.05)$ & $(0.00)$ \\
& 0.07 & 0.07 & 0.05 & 0.06 & 4.45 \\
& $(0.06)$ & $(0.05)$ & $(0.03)$ & $(0.04)$ & $(0.00)$ \\
\hline
\end{tabular}

See notes to Table 2. T-statistic is for the mean differences of each variable between the fourth and first quartiles. Median values are in parentheses.

Table 3

Panel B: Mean differences of Cash between countries

\begin{tabular}{lcccc}
\hline & France & Germany & Japan & UK \\
\hline Germany & 3.77 & & & \\
& $(0.00)$ & & & \\
Japan & -6.08 & -12.32 & & \\
& $(0.00)$ & $(0.00)$ & & \\
UK & 1.66 & -2.71 & 9.15 & \\
& $(0.09)$ & $(0.01)$ & $(0.00)$ & \\
US & 6.65 & 2.51 & 15.99 & 6.51 \\
& $(0.00)$ & $(0.01)$ & $(0.00)$ & $(0.00)$ \\
\hline
\end{tabular}

The hypothesised mean difference is zero. T-statistics values are shown above p-values. 
Table 4

Cash holdings and firm-specific factors with country dummies

\begin{tabular}{|c|c|c|c|c|c|c|}
\hline & Pooled & France & Germany & Japan & UK & US \\
\hline \multirow[t]{2}{*}{ Constant } & $0.17^{* * * *}$ & $0.24^{* * *}$ & $0.22^{* * * *}$ & $0.18^{* * *}$ & $0.24^{* * *}$ & $0.07^{* *}$ \\
\hline & $(0.01)$ & $(0.07)$ & $(0.05)$ & $(0.03)$ & $(0.03)$ & $(0.04)$ \\
\hline \multirow[t]{2}{*}{ Cash Flow } & $-0.19^{* * * *}$ & 0.04 & -0.03 & -0.10 & $-0.2055^{* * *}$ & $-0.2274^{* * * *}$ \\
\hline & $(0.03)$ & $(0.09)$ & $(0.09)$ & $(0.08)$ & $(0.06)$ & $(0.05)$ \\
\hline \multirow[t]{2}{*}{ Leverage } & $-0.48^{* * * *}$ & $-0.49^{* * * *}$ & $-0.33^{* * * *}$ & $-0.63^{* * *}$ & $-0.53^{* * * *}$ & $-0.41^{* * * *}$ \\
\hline & $(0.03)$ & $(0.13)$ & $(0.10)$ & $(0.04)$ & $(0.09)$ & $(0.05)$ \\
\hline \multirow[t]{2}{*}{ Leverage $^{2}$} & $0.46^{* * * *}$ & $0.51^{* *}$ & $0.30^{*}$ & $0.53^{* * * *}$ & $0.69^{* * * * *}$ & $0.43^{* * * *}$ \\
\hline & $(0.04)$ & $(0.21)$ & $(0.17)$ & $(0.06)$ & $(0.19)$ & $(0.06)$ \\
\hline \multirow[t]{2}{*}{ Liquidity } & $0.02^{* * *}$ & $-0.14^{* * * *}$ & $-0.05^{* * *}$ & $-0.07^{* * * *}$ & $-0.13^{* * * *}$ & $0.03^{* * *}$ \\
\hline & $(0.00)$ & $(0.05)$ & $(0.02)$ & $(0.02)$ & $(0.03)$ & $(0.00)$ \\
\hline \multirow[t]{2}{*}{ Capex } & $-0.07^{* *}$ & $-0.20^{*}$ & $-0.28^{* *}$ & $-0.10^{* * *}$ & $-0.21^{* *}$ & 0.02 \\
\hline & $(0.03)$ & $(0.10)$ & $(0.14)$ & $(0.04)$ & $(0.09)$ & $(0.05)$ \\
\hline \multirow[t]{2}{*}{ Mkt-to-Book } & $0.01^{* * * *}$ & $0.02^{* * * *}$ & -0.00 & $0.02^{* * * *}$ & $0.01^{* * * *}$ & $0.01^{* * * *}$ \\
\hline & $(0.00)$ & $(0.01)$ & $(0.01)$ & $(0.01)$ & $(0.00)$ & $(0.00)$ \\
\hline \multirow[t]{2}{*}{ Size } & -0.00 & $-0.01^{*}$ & $-0.01^{*}$ & $0.00^{*}$ & -0.00 & 0.00 \\
\hline & $(0.00)$ & $(0.00)$ & $(0.00)$ & $(0.00)$ & $(0.00)$ & $(0.00)$ \\
\hline \multirow[t]{2}{*}{ Dividend } & $-0.01^{* *}$ & 0.01 & $0.03^{*}$ & -0.00 & -0.0220 & $-0.0195^{* * * *}$ \\
\hline & $(0.01)$ & $(0.02)$ & $(0.02)$ & $(0.01)$ & $(0.02)$ & (0.01) \\
\hline \multirow[t]{2}{*}{ Variability } & $0.13^{* * *}$ & -0.18 & 0.05 & 0.18 & 0.02 & $0.29^{* * *}$ \\
\hline & $(0.04)$ & $(0.14)$ & $(0.14)$ & $(0.13)$ & $(0.09)$ & $(0.06)$ \\
\hline \multirow[t]{2}{*}{ France } & $0.04^{* * * *}$ & & & & & \\
\hline & $(0.01)$ & & & & & \\
\hline \multirow[t]{2}{*}{ Germany } & -0.01 & & & & & \\
\hline & $(0.01)$ & & & & & \\
\hline \multirow[t]{2}{*}{ Japan } & $0.10^{* * * *}$ & & & & & \\
\hline & $(0.01)$ & & & & & \\
\hline \multirow[t]{2}{*}{$U S$} & $-0.03^{* * *}$ & & & & & \\
\hline & $(0.01)$ & & & & & \\
\hline Observations & 4,069 & 234 & 390 & 1,436 & 912 & 1,097 \\
\hline$F$-statistic & $58.42^{* * * *}$ & $3.11^{* * *}$ & $2.99^{* * *}$ & $28.07^{* * * *}$ & $9.05^{* * *}$ & $23.08^{* * *}$ \\
\hline Adjusted $R^{2}$ & 0.27 & 0.17 & 0.10 & 0.29 & 0.16 & 0.30 \\
\hline
\end{tabular}

Cash, the dependent variable, is the ratio of total cash and equivalent items to total assets. Cash Flow is the ratio of pre-tax profit plus depreciation to total assets. Leverage is the ratio of total debt to total assets. Liquidity is the ratio of current assets minus total cash and equivalent to total assets. Capex is the ratio of capital expenditures to total assets. Mkt-to-Book is the ratio of book value of total assets minus the book value of equity plus the market value of equity to book value of assets. Size is the log of total sales in 1996 prices. Dividend is equal to 1 if a firm pays dividend for a given year. Variability is the ratio of the standard deviation of cash flows to average total assets. Standard errors robust to heteroscedasticity are reported in parentheses. France, Germany, Japan and the US are country dummies where the UK is used as the base country. Industry dummies are included in all models. ${ }^{* * * * *}$ and ${ }^{*}$ indicate coefficient is significant at the 1,5 and 10 percent level, respectively. 
Table 5

Panel A: The impact of leverage and country-specific institutional and legal factors on cash holdings

\begin{tabular}{|c|c|c|c|c|}
\hline & $(1)$ & $(2)$ & (3) & $(4)$ \\
\hline Constant & $\begin{array}{c}0.09^{* * *} \\
(0.02)\end{array}$ & $\begin{array}{c}0.07^{* * * *} \\
(0.02)\end{array}$ & $\begin{array}{c}0.13^{* * *} \\
(0.01)\end{array}$ & $\begin{array}{c}0.15^{* * * *} \\
(0.01)\end{array}$ \\
\hline Cash Flow & $\begin{array}{c}-0.33^{* * * * *} \\
(0.02)\end{array}$ & $\begin{array}{c}-0.35^{* * * * *} \\
(0.02)\end{array}$ & $\begin{array}{c}-0.35^{* * * *} \\
(0.02)\end{array}$ & $\begin{array}{c}-0.34^{* * * *} \\
(0.02)\end{array}$ \\
\hline Leverage & $\begin{array}{c}-0.67^{* * * *} \\
(0.06)\end{array}$ & $\begin{array}{c}-0.30^{* * * *} \\
(0.08)\end{array}$ & $\begin{array}{c}-0.68^{* * * *} \\
(0.04)\end{array}$ & $\begin{array}{c}-0.69^{* * * *} \\
(0.05)\end{array}$ \\
\hline Leverage $^{2}$ & $\begin{array}{c}0.61^{* * *} \\
(0.08)\end{array}$ & $\begin{array}{c}0.24^{*} \\
(0.13)\end{array}$ & $\begin{array}{l}0.66^{* * *} \\
(0.06)\end{array}$ & $\begin{array}{c}0.63^{* * * *} \\
(0.08)\end{array}$ \\
\hline Liquidity & $\begin{array}{l}0.01^{* * *} \\
(0.00)\end{array}$ & $\begin{array}{c}0.00 \\
(0.00)\end{array}$ & $\begin{array}{l}-0.00 \\
(0.00)\end{array}$ & $\begin{array}{l}-0.00 \\
(0.00)\end{array}$ \\
\hline Capex & $\begin{array}{l}-0.08^{* * *} \\
(0.03)\end{array}$ & $\begin{array}{c}-0.07^{* *} \\
(0.03)\end{array}$ & $\begin{array}{c}-0.06^{* *} \\
(0.03)\end{array}$ & $\begin{array}{l}-0.06^{* *} \\
(0.03)\end{array}$ \\
\hline Mkt-to-Book & $\begin{array}{c}0.01^{* * * *} \\
(0.00)\end{array}$ & $\begin{array}{c}0.01^{* * * *} \\
(0.00)\end{array}$ & $\begin{array}{c}0.01^{* * * *} \\
(0.00)\end{array}$ & $\begin{array}{c}0.01^{* * * *} \\
(0.00)\end{array}$ \\
\hline Size & $\begin{array}{c}0.01^{* * *} \\
(0.00)\end{array}$ & $\begin{array}{c}0.01^{* * *} \\
(0.00)\end{array}$ & $\begin{array}{c}0.01^{* * *} \\
(0.00)\end{array}$ & $\begin{array}{c}0.01^{* * * *} \\
(0.00)\end{array}$ \\
\hline Dividend & $\begin{array}{l}-0.01 \\
(0.01)\end{array}$ & $\begin{array}{l}-0.00 \\
(0.01)\end{array}$ & $\begin{array}{l}-0.01 \\
(0.01)\end{array}$ & $\begin{array}{l}-0.01^{*} \\
(0.01)\end{array}$ \\
\hline Variability & $\begin{array}{c}0.07^{*} \\
(0.04)\end{array}$ & $\begin{array}{c}0.08^{*} \\
(0.04)\end{array}$ & $\begin{array}{c}0.07^{*} \\
(0.04)\end{array}$ & $\begin{array}{c}0.08^{*} \\
(0.04)\end{array}$ \\
\hline Creditor & $\begin{array}{l}-0.00 \\
(0.00)\end{array}$ & & & \\
\hline Anti-director & & $\begin{array}{c}0.01^{* * * *} \\
(0.00)\end{array}$ & & \\
\hline Ownership & & & & $\begin{array}{c}-0.20^{* * * *} \\
(0.03)\end{array}$ \\
\hline Creditor ratio & & & $\begin{array}{c}-0.03^{* * * *} \\
(0.01)\end{array}$ & \\
\hline Leverage* Creditor & $\begin{array}{c}0.04^{*} \\
(0.03)\end{array}$ & & & \\
\hline Leverage ${ }^{2} *$ Creditor & $\begin{array}{l}-0.02 \\
(0.04)\end{array}$ & & & \\
\hline Leverage*Anti-director & & $\begin{array}{c}-0.08^{* * *} \\
(0.02)\end{array}$ & & \\
\hline Leverage $e^{2} *$ Anti-director & & $\begin{array}{l}0.08^{* * * *} \\
(0.03)\end{array}$ & & \\
\hline Leverage*Ownership & & & & $\begin{array}{l}0.53^{* *} \\
(0.25)\end{array}$ \\
\hline Leverage ${ }^{2} *$ Ownership & & & & $\begin{array}{l}-0.28 \\
(0.41)\end{array}$ \\
\hline Leverage ${ }^{*}$ Creditor Ratio & & & $\begin{array}{c}0.11^{* * *} \\
(0.03)\end{array}$ & \\
\hline Leverage ${ }^{2} *$ Creditor Ratio & & & $\begin{array}{l}-0.09^{*} \\
(0.06)\end{array}$ & \\
\hline Observations & 4,069 & 4,069 & 4,069 & 4,069 \\
\hline$F$-statistic & $48.41^{* * *}$ & $47.96^{* * * *}$ & $48.96^{* * *}$ & $49.97^{* * * *}$ \\
\hline Adjusted $R^{2}$ & 0.23 & 0.22 & 0.23 & 0.23 \\
\hline
\end{tabular}


Table 5

Panel B: Country-specific characteristics and turning points

\begin{tabular}{cccccccc}
\hline $\begin{array}{c}\text { Creditor } \\
\text { rights }\end{array}$ & $\begin{array}{c}\text { Turning } \\
\text { Points }\end{array}$ & $\begin{array}{c}\text { Anti- } \\
\text { director } \\
\text { rights }\end{array}$ & $\begin{array}{c}\text { Turning } \\
\text { points }\end{array}$ & $\begin{array}{c}\text { Creditor } \\
\text { ratio }\end{array}$ & $\begin{array}{c}\text { Turning } \\
\text { points }\end{array}$ & $\begin{array}{c}\text { Ownership } \\
\text { concentration }\end{array}$ & $\begin{array}{c}\text { Turning } \\
\text { points }\end{array}$ \\
\hline & & & & & & & \\
0 & 0.55 & 1 & 0.57 & 0 & 0.52 & 0.12 & 0.52 \\
1 & 0.53 & 2 & 0.54 & 0.20 & 0.52 & 0.13 & 0.52 \\
2 & 0.51 & 3 & 0.52 & 0.67 & 0.51 & 0.15 & 0.52 \\
3 & 0.48 & 4 & 0.51 & 1 & 0.51 & 0.24 & 0.50 \\
4 & 0.46 & 5 & 0.50 & 3 & 0.48 & 0.50 & 0.43 \\
\hline
\end{tabular}

See notes to Tables 1 to 3, and also La Porta et al. $(1997,1998)$ for the values of country-specific factors. 